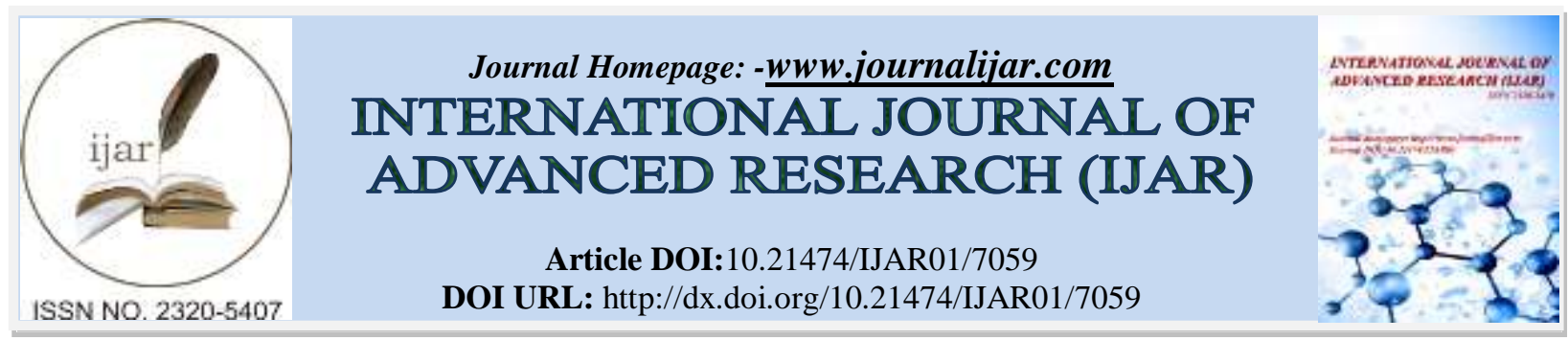

RESEARCH ARTICLE

\title{
WATERSHED IDENTIFICATION AND ITS EFFECT TOWARD FLOOD (CASE STUDY: MAKASSAR CITY).
}

\begin{abstract}
Sudirman $^{1}$, Slamet Trisutomo ${ }^{2}$, Roland A. Barkey ${ }^{3}$ and Mukti Ali ${ }^{2}$.
1. Architecture Department, Engineering Faculty, Hasanuddin University, Gowa, 92173, Indonesia.

2. Laboratory of Waterfront City, Engineering Faculty, Hasanuddin University, Gowa, 92173, Indonesia.

3. Laboratory of Planning and Forestry Information System, Forestry Faculty, Hasanuddin University, Makassar, 90245, Indonesia.
\end{abstract}

\section{Manuscript Info}

Manuscript History

Received: 08 March 2018

Final Accepted: 10 April 2018

Published: May 2018

Keywords:-

Watershed, Identification, Geographic Information System (GIS), Flood, Makassar City.

\section{Abstract}

The city of Makassar is located in Maros, Tabaringan, Tallo, Jeneberang and Gowa-Takalar watersheds and Makassar nonwatershed areas.This area is located along the coast of Makassar City whose stream flow is directly mainly to the sea or through small rivers (creek ). For the calculation of flood discharge, the study of watershed becomes crucial to know the position of study area to the influence of upstream river basin. Watershed area is very influential to flood discharge.In general, the larger the watershed the greater the amount of surface runoff is so that the greater the flow of surface or flood discharge. This study aims to identify the watershed and its effect towards floods in Makassar. By using an integrated spatial analysis method in Geographic Information Systems (SIG) version 10.5 application, the watershed of Makassar can be identified. The results show that watershed in Jeneberang region is the largest watershed area that empties into Makassar City. The watershed reaches 76,085.06 hectares while the Gowa-Takalar watershed is the smallest of 1.88 hectares. There are 2 watershed areas that have no effect on the risk of flood in Makassar City namely Maros watershed and Gowa-Takalar watershed. The research results can be utilized for water resource management needs such as primary and secondary flow planning, both by practitioners and the government of Makassar City.

Copy Right, IJAR, 2018,. All rights reserved.

\section{Introduction:-}

Watershed is a land area that is adjuncted with the river and its tributaries bounded by the ridges of mountains. This serves to accommodate, store, and drain water that derive from rainfall to the lake or to the sea naturally (Candra, 2003; Triatmodjo, 2013; Prastiwi, 2014; Yin, Yu, et all, 2016). From the place of origin to the end of the sea or from the geographical location of the river can be categorized into three main parts: the upstream (mountain), transition and downstream areas (beach), these three areas also show the nature and characteristics of different river systems (Kodoatie, 2013). 
Land utilization is one component of watershed, so when the watershed component changes mainly land use, it indirectly influences the flow of flow (Febryanto, 2016; Brogna et al., 2017; Liu \& Shi, 2017). Wide watersheds are very influential to river flow, in general the larger the watershed the greater the amount of surface runoff so that the greater the flow of surface or river flow, the measurement of river length and length of the watershed is important in the analysis of runoff flow and river flow discharge (Triatmodjo, 2013; Sajikumar \& Remya, 2014; Szczypta et al., 2015). The amount of flow within the river that affects the flood discharge, flood pattern is determined mainly by the amount of rain, the rain intensity, the area of rain, the time of rain, the area of the river and the characteristics of the flow areas such as topography, plants and geology (Subarkah, 1980; Takeda, 1983; Potdar, 2016).

The development of Geographic Information Systems supported by cutting-edge technology allows the mapping of natural resources well to facilitate work processes (Candra, 2003; Haque \& Basak, 2017; Kourgialas \& Karatzas, 2016; H. Liu, Lu, et all, 2012; Zhang \& Pan, 2014; Sarhadi, Soltani, et all, 2012). With the ease and advantages provided in remote sensing and Geographic Information System, it will help identifying and mapping the watershed causing floods in Makassar city.

This study aims to identify the watershed that affect flooding in the city of Makassar. Identification is done by using application based on Geographic Information System (GIS). The results will be used to calculate flood discharge in Makassar city.

\section{Data and Method:-}

\section{Research Object}

The study is located in Makassar City, the boundary of the research area is determined based on the boundaries of the districts that have the coastline. The delineation of the research object is shown in Figure 1.

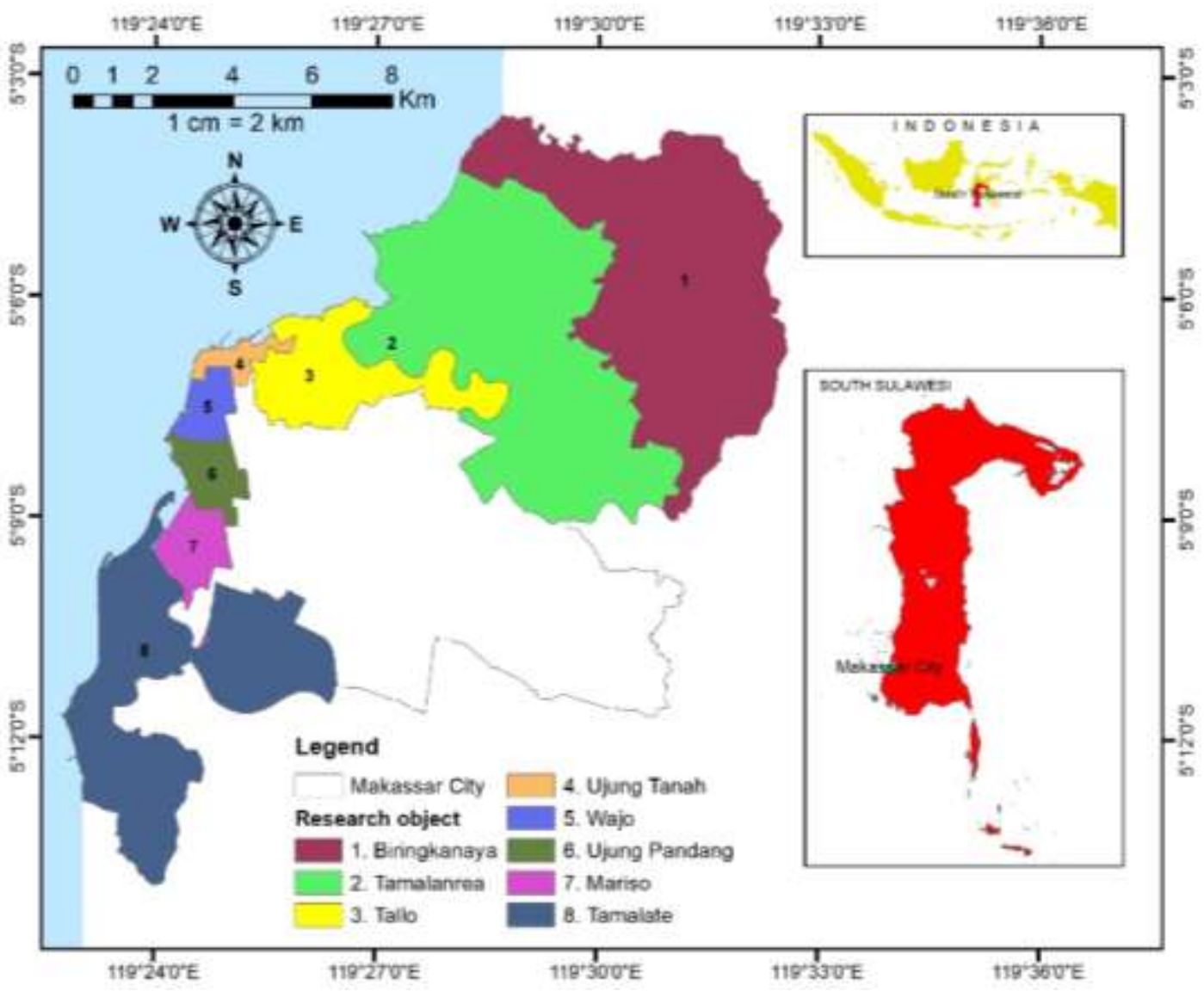

Figure 1:-Research object 


\section{Source of Research Data:-}

Data used is DEM (digital elevation model) residing in column / line (114/64), Entity ID: ASTGDEMV2_0S06E119, date of acquisition October 17th 2011, accessed on site: https://earthexplorer.usgs.gov/.

\section{Analysis Technique:-}

By utilizing the application of Geographic Information System (SIG) version 10.5 from ESRI Indonesia, the watershed is identified by spatial analysis method which is done by several stages, including; map algebra, hydrology, raster calculator, flow direction, flow accumulation, stream link and watershed.

\section{Results and Discussion:-}

The results showed that Makassar City consists of 5 watershed areas ie Maros watershed, Tabaringan watershed, Tallo watershed, Jeneberang watershed and Gowa-Takalar watershed. Some areas of Makassar City are nonwatershed as informed in Figure 2.

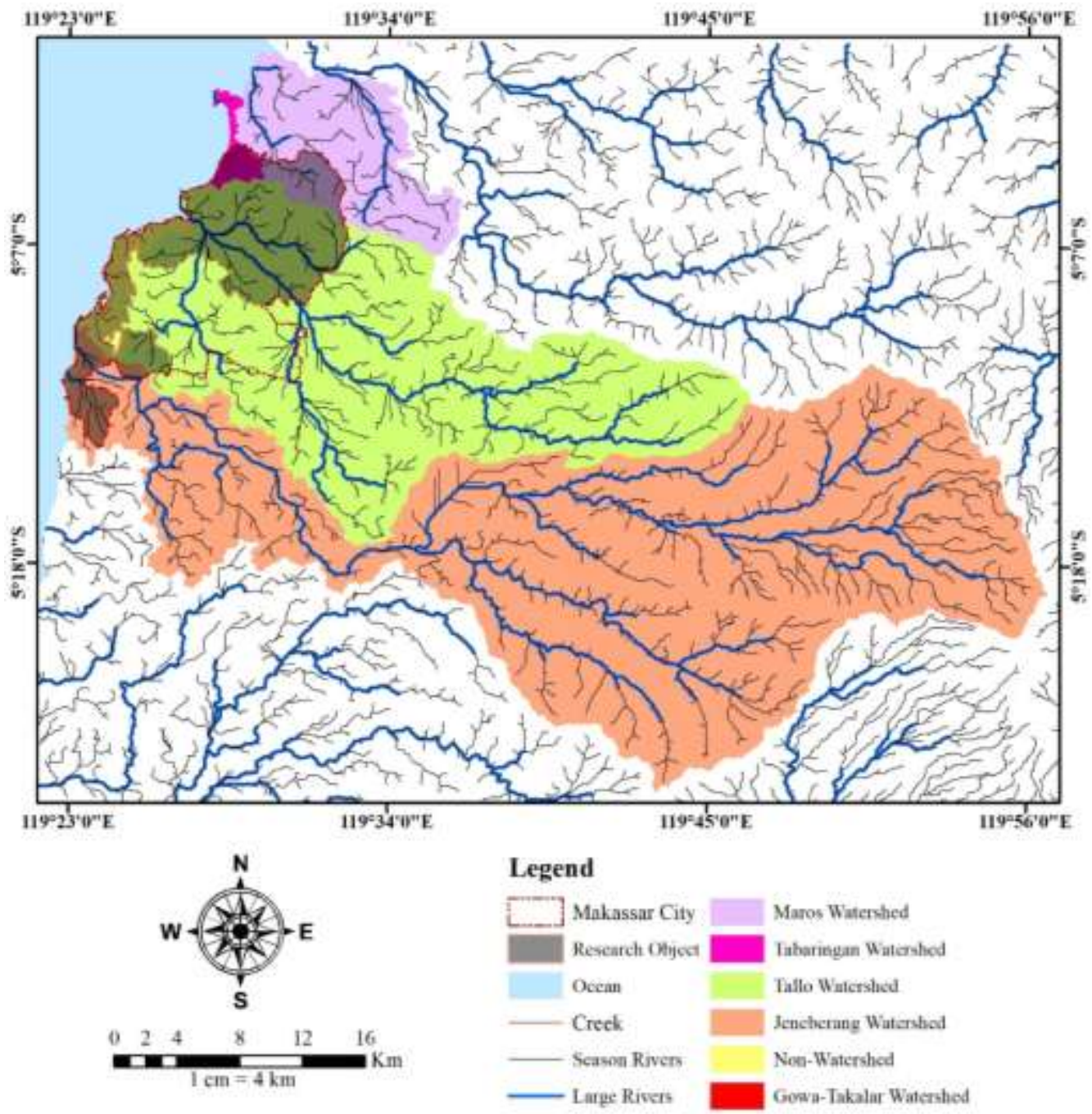

Figure 2:-Watershed that affect of the Makassar City

As it is known that the area of a watershed is a component of several equations to calculate the flood discharge (Q). The rational method approach uses the equation $\mathrm{Q}=0.278 \mathrm{CIA}$, where " $\mathrm{A}$ " is the area of the watershed in units of square kilometers (Kodoatie, 2013; Samaawa, 2016). The watershed in association with Makassar City as shown in Table 1. 
Table 1:-Watershed that associated with Makassar City

\begin{tabular}{|l|r|r|}
\hline \multicolumn{1}{|c|}{ Description } & Area (Ha) & Percent (\%) \\
\hline Maros watershed & $10,223.34$ & 7.698 \\
\hline Tabaringan watershed & 850.76 & 0.641 \\
\hline Tallo watershed & $43,853.74$ & 33.023 \\
\hline Jeneberang watershed & $76,085.06$ & 57.294 \\
\hline Makassar non-watershed & $1,783.77$ & 1.343 \\
\hline Gowa-Takalar watershed & 1.88 & 0.001 \\
\hline Total & $132,798.55$ & 100.00 \\
\hline
\end{tabular}

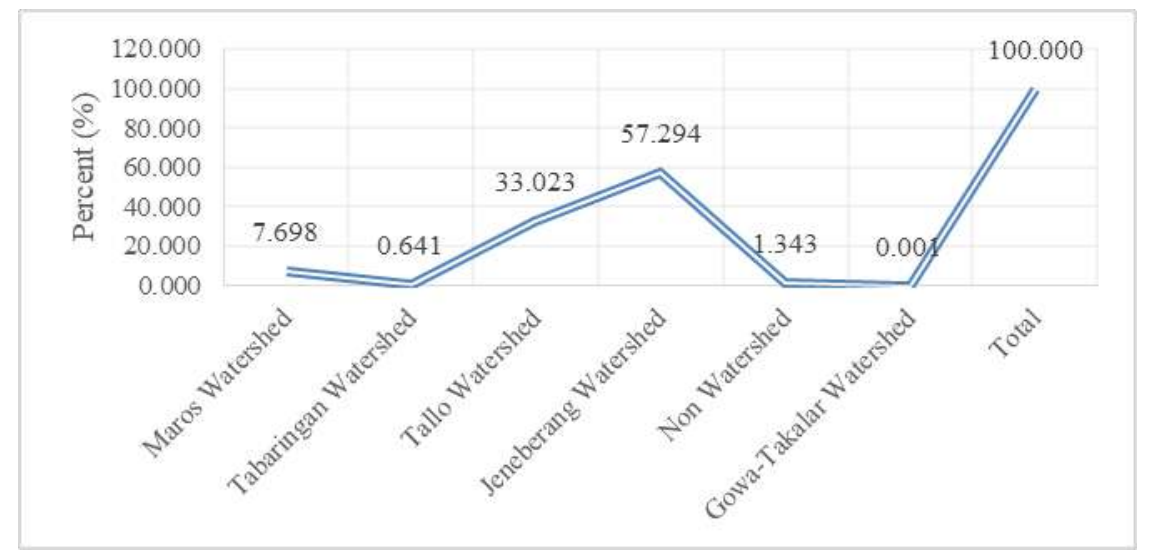

Figure 3:-Graph of watershed that associated with Makassar City

Based on Figure 2, can be determined the watershed that influences the flood at the research object. Data of each watershed as indicated in Table 2.

Tabel 2:-Watershed that effect flood at research object

\begin{tabular}{|l|c|r|r|}
\hline \multicolumn{1}{|c|}{ Description } & Effect towards flood & Wide (Ha) & Percent (\%) \\
\hline Maros watershed & No effect & $1,290.07$ & 10.89 \\
\hline Tabaringan watershed & Have effect & 550.95 & 4.65 \\
\hline Tallo watershed & Have effect & $6,813.06$ & 57.50 \\
\hline Jeneberang watershed & Have effect & $1,409.45$ & 11.89 \\
\hline Makassar non-watershed & Have effect & $1,783.77$ & 15.05 \\
\hline Gowa-Takalar watershed & No effect & $11,849.18$ & 0.02 \\
\hline \multicolumn{2}{|r|}{ Total } & &
\end{tabular}

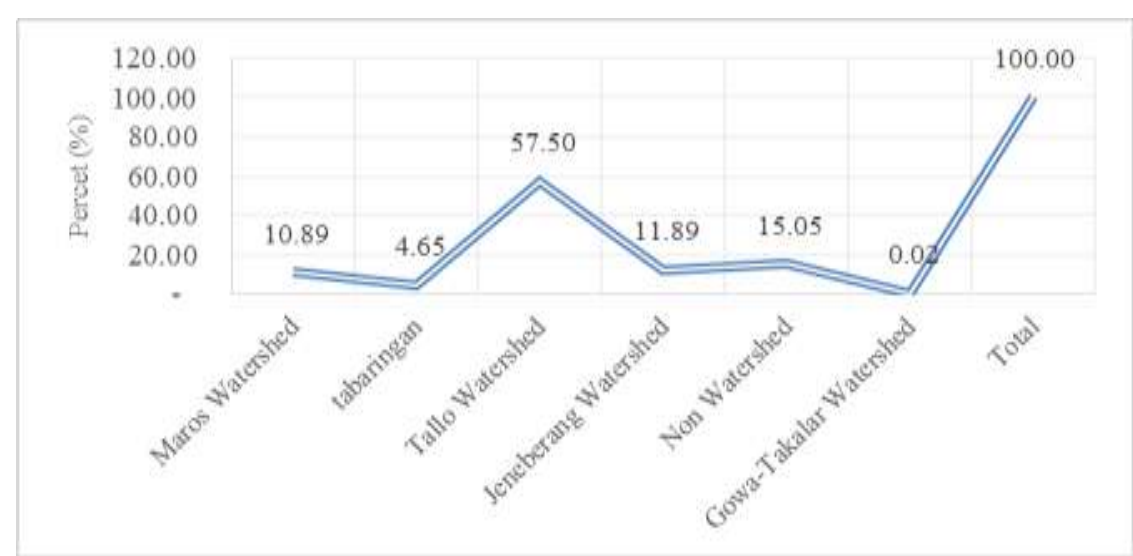

Figure 4:-Graph of watershed that effect flood at research object 


\section{Shape of watershed:-}

Watershed has various forms based on topography and geology. Broadly speaking the form of the watershed (Kinori\&Mevorach) is grouped into 3 (three) namely: elongated shape, widened shape and fan shape (Kodoatie, 2010).

\section{Maros watershed and Tabaringan non-watershed:-}

The Maros watershed can not be defined because it is not described as a whole, while the Tabaringan watershed is categorized as fan-shaped and its drainage is creek. The watershed shape is shown in Figure 5.

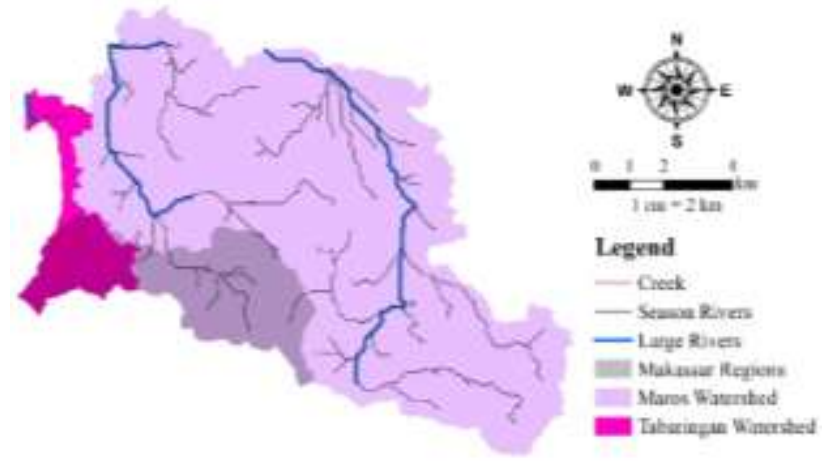

Figure 5:-Shape of Maros watershed and Tabaringan watershed

\section{Tallo watershed:-}

The Tallo watershed is categorized as an elongated watershed because the ratio between the length and width of the basin is greater than 1:1,7 (Richards, 1950) in (Kodoatie, 2013).

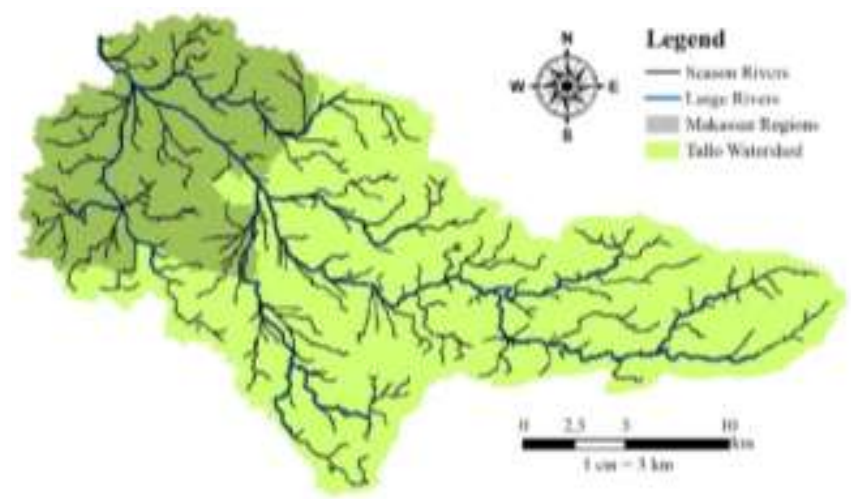

Figure 6:-Shape of Tallo watershed

Jeneberang watershed:-

Based on Figure 7, can be stated that Jeneberang watershed belongs to the category of elongated shape. 


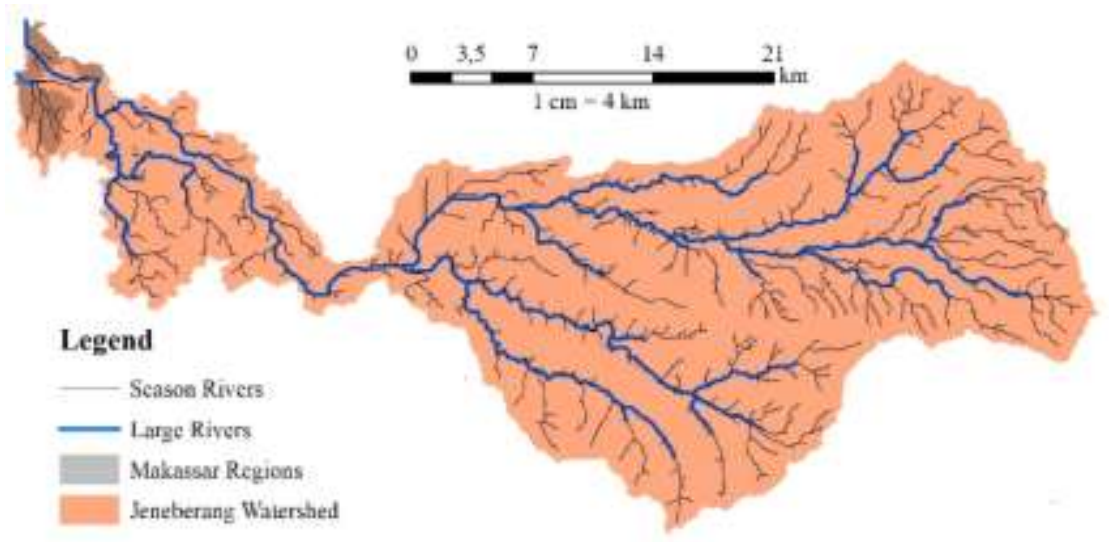

Figure 7:-Shape of Jeneberang watershed

\section{Makassar non-watershed and Gowa-Takalar watershed:-}

The Makassar non-watershed can not be defined as a watershed due to its drainage in the coastal region of Makassar City, as well as the Gowa-Takalar watershed is not undefined because it is not described as a whole. The watershed shape is shown in Figure 8.

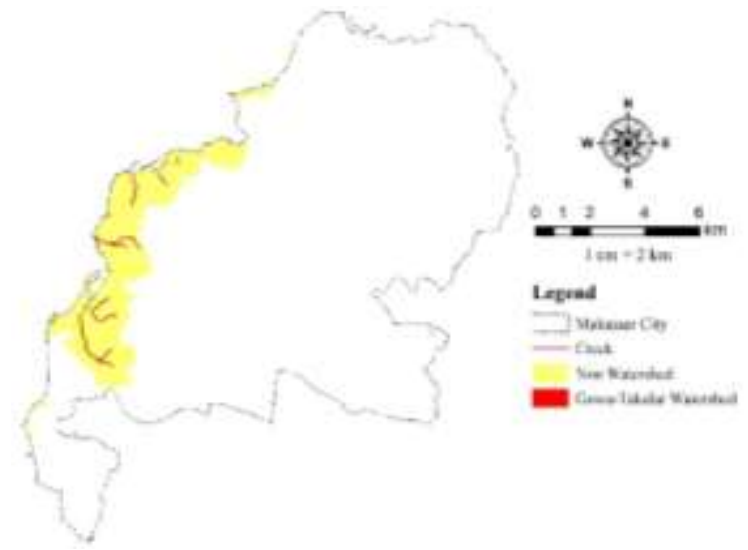

Figure 8:-Shape of Makassar non-watershed and Gowa-Takalar watershed

\section{Conclusion:-}

The results show that Makassar is located in Maros watershed, Tabaringan watershed, Tallo watershed, Jeneberang watershed, Gowa-Takalar watershed and Makassar Non-watershed. Jeneberang watershed is the largest watershed area that empties into Makassar City, the watershed reaches 76,085.06 hectares while the Gowa-Takalar watershed is the smallest of 1.88 hectares. There are 2 (two) watershed areas that have no effect on flood in Makassar City namely Maros watershed and Gowa-Takalar watershed, the runoff of both watersheds flows out of Makassar area when it rains. In the research object, the area of each watershed ie Maros watershed covering 1,290.07 hectares, Tabaringan watershed covering 550.95 hectares, Tallo watershed covering 6,813.06 hectares, Jeneberang watershed 1,409.45 hectares, non-watershed of Makassar covering 1,783.77 hectares and Gowa-Takalar 1.88 hectares. The shape of each watershed ie Tallo and Jeneberang watershed shaped elongated, Tabaringan watershed is categorized as fan-shaped, and others watershed undefined.

\section{Acknowledgement:-}

Thanks to ESRI Indonesia for supporting geographic information system (GIS) software in this research. 


\section{References:-}

1. Brogna, D., Vincke, C., Brostaux, Y., Soyeurt, H., Dufrêne, M., \& Dendoncker, N. (2017). How does forest cover impact water flows and ecosystem services? Insights from " real-life" catchments in Wallonia ( Belgium ). Ecological Indicators, 72, 675-685. https://doi.org/10.1016/j.ecolind.2016.08.011

2. Candra. (2003). Identifikasi dan Pemetaan Lahan Kritis di Daerah Aliran Sungai Ciliwung Hulu Kabupaten/Kota Bogor Dengan Menggunakan Penginderaan Jauh dan Sistem Informasi Geografis. Institut Pertanian Bogor.

3. Febryanto. (2016). Pengaruh Perubahan Penggunaan Lahan Terhadap Debit Puncak Sub-DAS Opak Hulu Tahun 2009 dan 2014 Menggunakan Citra Landsat 5 dan Landsat 8. Jurnal Bumi Indonesia, 5, 1-10.

4. Haque, I., \& Basak, R. (2017). Land cover change detection using GIS and remote sensing techniques: A spatio-temporal study on Tanguar Haor, Sunamganj, Bangladesh. The Egyptian Journal of Remote Sensing and Space Sciences. https://doi.org/10.1016/j.ejrs.2016.12.003

5. Kodoatie, R. J. (2010). Tata Ruang Air. Yogyakarta: Andi Yogyakarta.

6. Kodoatie, R. J. (2013). Rekayasa dan Manajemen Banjir Kota. Yogyakarta: Andi Yogyakarta.

7. Kourgialas, N. N., \& Karatzas, G. P. (2016). A flood risk decision making approach for Mediterranean tree crops using GIS; climate change effects and flood-tolerant species. Environmental Science \& Policy, 63, 132142. https://doi.org/10.1016/j.envsci.2016.05.020

8. Liu, H., Lu, Y., \& Wang, Z. (2012). Gis Approach Of Inundation Analysis In The Dongjiang(East River) Drainage Area. Procedia Environmental Sciences, 12(Icese 2011), 1063-1070. https://doi.org/10.1016/j.proenv.2012.01.388

9. Liu, J., \& Shi, Z. (2017). Quantifying land-use change impacts on the dynamic evolution of flood vulnerability. Land Use Policy, 65(April), 198-210. https://doi.org/10.1016/j.landusepol.2017.04.012

10. Potdar, M. B. (2016). Impact Assessment of Watershed Management Programmes on Land Use/Land Cover Dynamics using Remote Sensing and GIS. Remote Sensing Applications: Society and Environment. https://doi.org/10.1016/j.rsase.2016.12.001

11. Prastiwi, T. H. (2014). Pemanfaatan Data Penginderaan Jauh untuk Identifikasi Kerusakan Hutan di Daerah Alitan Sungai (DAS) (Studi Kasus: Sub DAS Brantas Bagian Hulu, Kota Batu). Teknik Pomits, x(x).

12. Sajikumar, N., \& Remya, R. S. (2014). Impact of land cover and land use change on runoff characteristics. Journal of Environmental Management. https://doi.org/10.1016/j.jenvman.2014.12.041

13. Samaawa, H. (2016). Estimasi Debit Puncak Berdasarkan Beberapa Metode Penentuan Koefisien Limpasan di Sub DAS Kedung Gong, Kabupaten Kulonprogo, Yogyakarta. Jurnal Bumi Indonesia, 5.

14. Sarhadi, A., Soltani, S., \& Modarres, R. (2012). Probabilistic flood inundation mapping of ungauged rivers: Linking GIS techniques and frequency analysis. Journal of Hydrology, 458-459, 68-86. https://doi.org/10.1016/j.jhydrol.2012.06.039

15. Subarkah, I. (1980). Hidrologi Untuk Perencanaan Bangunan Air (Cetakan Ke). Bandung: Angkasa Offset.

16. Szczypta, C., Gascoin, S., Houet, T., Hagolle, O., Dejoux, J., Vigneau, C., \& Fanise, P. (2015). Impact of climate and land cover changes on snow cover in a small Pyrenean catchment. JOURNAL OF HYDROLOGY, 521, 84-99. https://doi.org/10.1016/j.jhydrol.2014.11.060

17. Takeda, K. (1983). Hidrologi Untuk Pengairan. (S. Sosrodarsono, Ed.). Jakarta.

18. Triatmodjo, B. (2013). Hidrologi Terapan (Ketiga). Yogyakarta: Beta Offset Yogyakarta.

19. Yin, J., Yu, D., \& Wilby, R. (2016). Modelling the impact of land subsidence on urban pluvial flooding: A case study of downtown Shanghai, China. Science of the Total Environment, 544(July 2011), 744-753. https://doi.org/10.1016/j.scitotenv.2015.11.159

20. Zhang, S., \& Pan, B. (2014). An urban storm-inundation simulation method based on GIS. Journal of Hydrology, 517, 260-268. https://doi.org/10.1016/j.jhydrol.2014.05.044 